\title{
BERM RECESSION OF THE ICELANDIC-TYPE BERM BREAKWATER
}

\author{
Sigurdur Sigurdarson ${ }^{1}$, Jentsje W van der Meer $^{2}$, Alf Tørum ${ }^{3}$ and \\ Roberto Tomasicchio ${ }^{4}$
}

\begin{abstract}
The purpose of this paper is to analyse the recession of the Icelandic-type berm breakwater. This limits the interest from the whole profile in dynamic structures, like reshaping berm breakwaters or single beaches, to the start of and early stages of reshaping. A large part of the PIANC (2003) recession data is found to be irrelevant to the Icelandic-type berm breakwaters. Design specifications for the Icelandic-type berm breakwater with respect to the berm are outlined. Requirements for the type of data needed are defined and three data sets are identified. A new formula for the recession of the Icelandic-type berm breakwater is presented, where the recession is a function of $\mathrm{H}_{\mathrm{o}} \mathrm{T}_{\mathrm{op}}$ with much less scatter than the earlier formula.
\end{abstract}

\section{INTRODUCTION}

The reshaping and berm recession of statically as well as dynamically stable breakwaters has moved in two directions. From the point of dynamically stable breakwaters up to dynamically stable shingle beaches, the whole reshaped profile is of importance. This area has been investigated by Van der Meer (1988) and has resulted in a procedure in BREAKWAT, where the full reshaped profile is calculated as function of hydraulic conditions and structure geometry.

Berm breakwaters are at the "lower end" of dynamic stability and reshaping is very often limited and in the area of static stability (some reshaping allowed, but then stable). PIANC (2003) classifies the berm breakwaters as follows, where $H_{0}=H_{s} / \Delta D_{n 50}$ and $T_{o m}=T_{m}\left(g / D_{50}\right)^{0.5}$

\begin{tabular}{lcc} 
Type of breakwater & $\mathrm{H}_{0}$ & $\mathrm{H}_{0} \mathrm{~T}_{\text {om }}$ \\
\hline Statically stable non-reshaped berm breakwater & $<1.5-2$ & $<20-40$ \\
Statically stable reshaped berm breakwater & $1.5-2.7$ & $40-70$ \\
Dynamically stable reshaped berm breakwater & $>2.7$ & $>70$
\end{tabular}

For statically stable non-reshaped and reshaped berm breakwaters, the profile reshaping is limited and the actual area of interest is the erosion of the berm, or the so-called recession Rec. Various formulae have been derived for this recession of a berm, sometimes far into the area of dynamic stability, where profile reshaping is dependent on

\footnotetext{
${ }^{1}$ Icelandic Maritime Administration, Iceland, sigurdur@sigling.is

${ }^{2}$ Van Der Meer Consulting BV, The Netherlands, jm@vandermeerconsulting.nl

${ }^{3}$ Norwegian University of Science and Technology, Norway, alf.torum@ntnu.no

${ }^{4}$ University of Salento, Italy, roberto.tomasicchio@unile.it
} 
structure geometry and where the use of BREAKWAT would simply give the full profile (say for $\mathrm{H}_{0}>2.7$ ).

The Icelandic-type berm breakwater is a structure that is designed with very limited recession, even under design conditions. The present analysis focuses on this type of breakwater only and on the stability/recession of the berm.

\section{ICELANDIC-TYPE BERM BREAKWATER}

The Icelandic-type berm breakwater has been developed through a number of breakwater projects over the past two decades for a design wave height up to $\mathrm{H}_{s}=7.5 \mathrm{~m}$. Some of these structures have already experienced waves close to or even exceeding the design conditions. A list of some of the more recent breakwater projects in Iceland and Norway is shown in Table 1, with the construction period and design wave height for the most exposed section of the breakwater, see Sigurdarson et al. 2006.

Table 1. Recently constructed Icelandic-type berm breakwater

\begin{tabular}{lcccc}
\hline Breakwater & Constr.year & $\mathrm{H}_{\mathrm{s}}$ & $\mathrm{H}_{\circ}$ & $\mathrm{H}_{\mathrm{o}} \mathrm{T}_{\mathrm{om}}$ \\
\hline Sirevåg berm breakwater, Norway & $2000-2001$ & $7.0 \mathrm{~m}$ & 2.1 & 48 \\
Húsavík berm breakwater, Iceland & $2001-2002$ & $6.8 \mathrm{~m}$ & 1.9 & 52 \\
Grindavík berm breakwater, Iceland $^{1)}$ & $2001-2002$ & $5.1 \mathrm{~m}$ & 1.5 & 47 \\
Hammerfest berm brkw, Norway $^{2}$ & $2002-2003$ & $7.5 \mathrm{~m}$ & 2.2 & 57 \\
Vopnafjörður breakwater, Iceland $^{2)}$ & $2003-2004$ & $4.0 \mathrm{~m}$ & $1.3 / 1.9$ & $40 / 68$ \\
Porlákshöfn berm brkw, Iceland & $2004-2005$ & $5.7 \mathrm{~m}$ & 1.9 & 60 \\
\hline 1) Stone class I was only used on the breakwater head & & \\
2) $\quad$ The Vopnafjörður breakwater is a low structure, a combination of a conventional \\
and a berm type breakwater, therefore values for stone classes I and II are listed
\end{tabular}

The reshaping berm breakwater as built in the eighties has evolved into a more stable berm breakwater by utilising large stones that are often available in few percentages in an armourstone quarry. This breakwater, which is referred to as the Icelandic-type berm breakwater, uses very large class I rock on top of the berm and partly down the down slope. The stones in this rock class are placed one by one and attention is given to the placement above low sea level in such a way that stability is increased. With respect to the berm, the following design specifications apply to the Icelandic-type berm breakwater:

- A narrow graded class I rock is present in two layers on top of the berm:

- from the edge to half way or more on the berm

- from the edge down the slope to at least low sea level

- Class II rock is present beneath the class I rock

- Upper and down slopes are about 1:1.5

- The berm level is about $0.65^{\star} \mathrm{H}_{\mathrm{s}}$ above design water level 
- Class I rock is designed with $\mathrm{H}_{\mathrm{o}}=\mathrm{H}_{\mathrm{s}} / \Delta \mathrm{D}_{\mathrm{n} 50} \approx 2$.

A typical example of an Icelandic-type berm breakwater is the Sirevåg berm breakwater in Norway, see Figure 1. The Class I rock is 2030 tonnes with a very narrow grading and the class II rock is 10-20 tonnes. In this example the Class I rock covers the full berm width. Reshaping under design conditions should be very limited, which gave the design requirement of $\mathrm{H}_{0}=\mathrm{H}_{\mathrm{s}} / \Delta \mathrm{D}_{\mathrm{n} 50} \approx 2$. In practice one is also interested in conditions beyond the design conditions, say a wave height which is $25 \%-40 \%$ larger. This actually results in a limit of about $\mathrm{H}_{0}=$ 2.7, or $\mathrm{H}_{0} \mathrm{~T}_{\mathrm{om}}=70$, which is also the transition to dynamically stable berm breakwaters. Also, recession should be limited to at least less than 10 Class I stones along the berm, towards the crest and possibly less than 5.

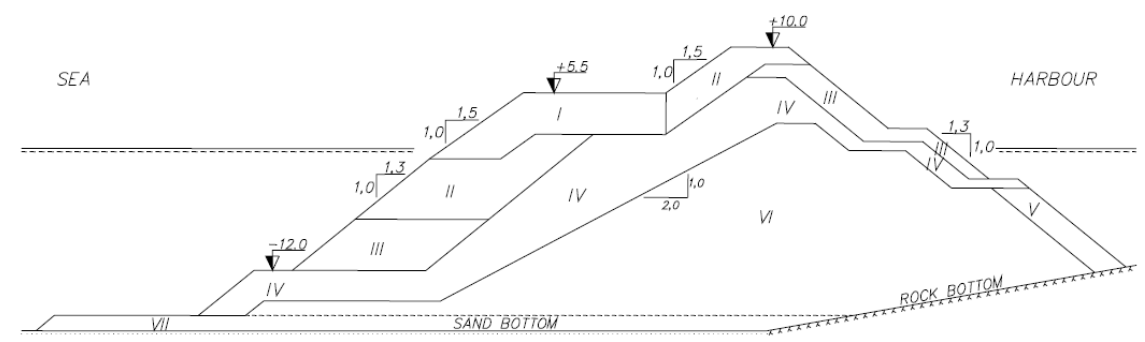

Figure 1. Typical cross-section of an Icelandic-type berm breakwater, the Sirevåg berm breakwater. Design wave height $\mathrm{H}_{\mathrm{s}, 100}=7.0 \mathrm{~m}, \mathrm{~T}_{\mathrm{z}}=10.6 \mathrm{~s}, \mathrm{H}_{\mathrm{o}} \mathrm{T}_{\mathrm{o}}=48$. Class I stones 20-30 tonnes, gradation factor $f_{g}=1.1$, class II stones 10-20 tonnes, Class III stones 4-10 tonnes and Class V stones 1-4 tonnes, Sigurdarson et al. (2003).

\section{AVAILABLE DATA AND RECESSION EQUATIONS}

PIANC (2003) presented recession data of many (research) projects, with partly Icelandic-type berm breakwaters, see Figure 2. A large scatter is present due to various influences which could not be made more specific. Some of them would be the definition of wave height (at the toe or more at deep water), placement of rock (dumped or carefully placed), way of measuring recession, etc.

PIANC (2003) gave a third order polynomial function for the recession, given by the middle line in Figure 2. Sigurdarson et al. (2007) changed this formula to a simple power function with a more accurate description of the reliability (see Figure 3 ), but deleting depth dependence

with:

$$
\begin{aligned}
& \operatorname{Rec} / D_{n 50}=0.037\left(H_{o} T_{\text {om }}-\mathrm{Sc}\right)^{1.34} \\
& \operatorname{Rec} / D_{n 50}=0 \text { for } H_{\circ} T_{\text {om }}<\mathrm{Sc} \\
& \mu(\mathrm{Sc})=20 \text { and } \sigma(\mathrm{Sc})=20
\end{aligned}
$$




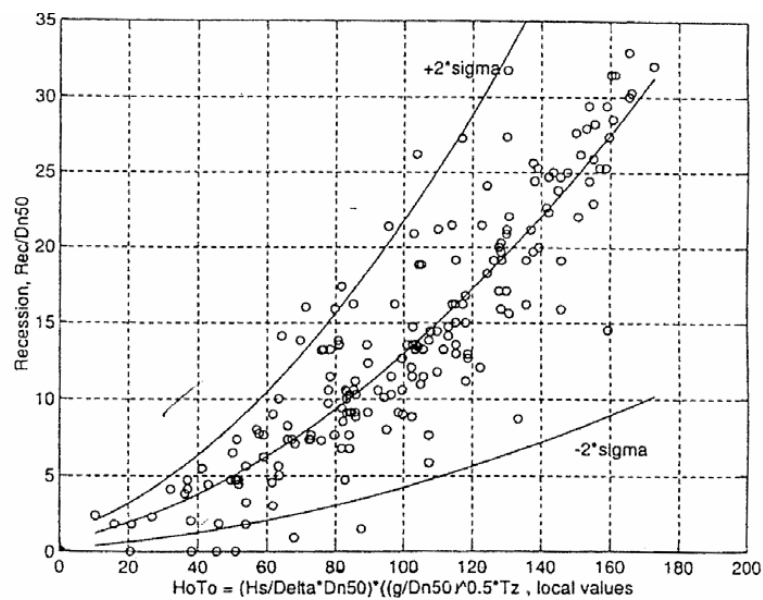

Figure 2. Recession data from PIANC (2003).

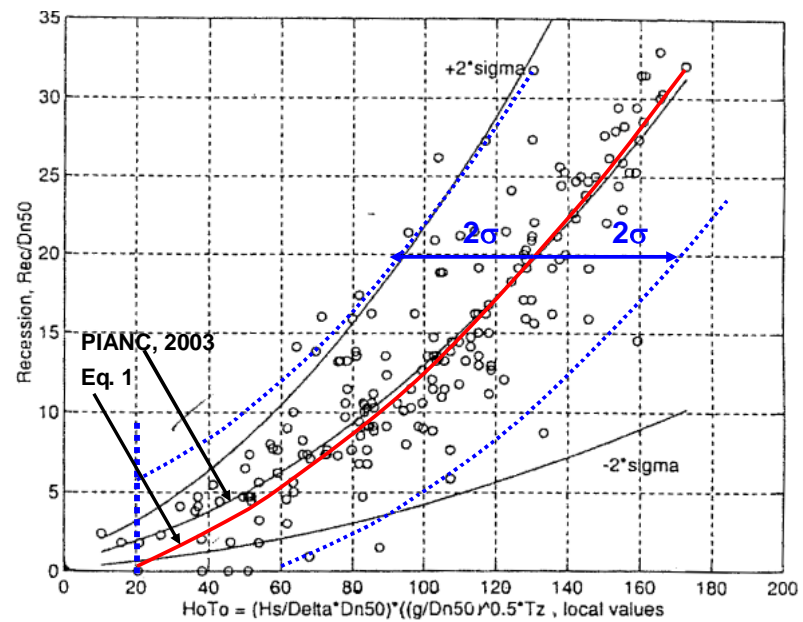

Figure 3. Recession data from PIANC (2003), including equation 1.

By focusing only on the problem of the Icelandic-type berm breakwaters changes the area of interest in Figures 2 and 3 remarkably. With the limits of $\mathrm{H}_{0} \mathrm{~T}_{\mathrm{om}}<70$ and not more than 10 stones removed along the berm $\left(R e c / D_{n 50}<10\right)$ leaves only the lower left corner of Figures 2 and 3 , see Figure 4. 


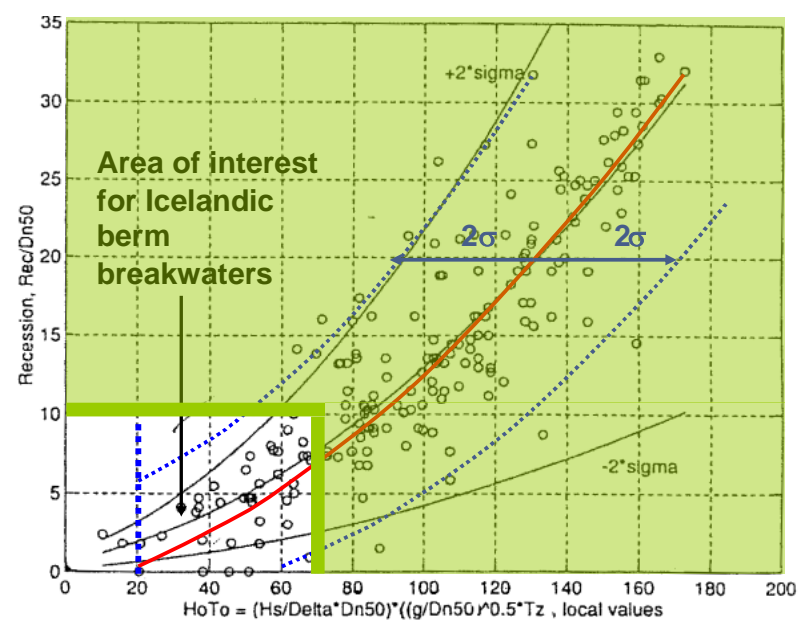

Figure 4. Recession data from PIANC (2003), with area of interest for Icelandic-type berm breakwaters.

When the interest is limited to the lower left corner of Figure 3 some interesting features appear. Data points are present which do not show any recession for $\mathrm{H}_{\mathrm{o}} \mathrm{T}_{\mathrm{om}}=40-50$, but recession could also be 7 or 8 stones wide. Also, recession of 2 stones wide is shown for $\mathrm{H}_{0} \mathrm{~T}_{\text {om }}$ values of only 10 . The only conclusion is that the data given in PIANC (2003) is not able to give any reliable design guideline for the Icelandic-type berm breakwater. More well-defined data is required to give such guidelines.

Requirements for such reliable data are:

- The cross-section should be an Icelandic-type berm breakwater (two layers of class I rock with underneath class II rock) with upper and down slopes of about 1:1.5.

- Any recession should not be influenced by the class II rock. The recession should not occur in the class II rock, only in the class I.

- The placing of the rock of class I above water should be done with care and the rock of class I should not be dumped.

- The class I rock should be narrow graded.

- Flume tests with perpendicular wave attack should be chosen.

- The wave height at the toe of the structure should be used and not at deeper water in case a foreshore is present.

For the time being this leads only to three data sets, which can be used to some extent: MAST II (1996 and 1997), Myhra (2005) and Sveinbjörnsson (2008). Each data set will be described in more detail.

MAST II (1996 and 1997)

Under the European Research project MAST II (contract MAS2CT94-0087) called Berm breakwater structures, flume tests were 
performed at $\mathrm{DHI}$ on the behaviour of using two main armour classes of rock in the berm (the principal of the Icelandic-type berm breakwater). In total, 12 different cross-sections were tested, but only two can be classified under the boundary conditions given above. These are profiles 3 and 4 as given in Figure 5 .

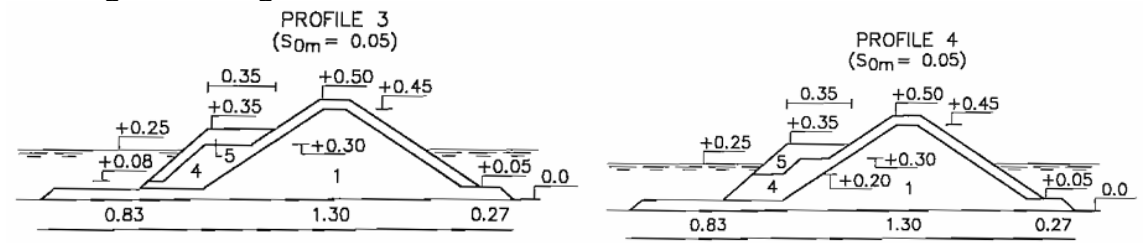

Figure 5. Icelandic-type berm breakwater profiles from MAST II (1996 and 1997).

In both cases class I rock was placed on the berm and down slope. It should be noted that the down slope is quite steep with 1:1.25. In the flume, a foreshore slope of 1:80 was present, giving a water depth at the toe of the berm breakwater of $0.25 \mathrm{~m}$.

Table 2. Data on recession from MAST II (1996 and 1997)

\begin{tabular}{|c|c|c|c|c|c|c|c|c|c|c|c|}
\hline set-up & water depth $(\mathrm{m})$ & $\mathrm{H}_{\mathrm{s}}(\mathrm{m})$ & $\mathrm{T}_{\mathrm{p}}(\mathrm{s})$ & $\mathrm{T}_{02}(\mathrm{~s})$ & $\mathrm{D}_{\mathrm{n} 50}(\mathrm{~m})$ & $\mathrm{H}_{\mathrm{o}}$ & $\mathrm{H}_{\mathrm{o}} \mathrm{T}_{\mathrm{op}}$ & $\mathrm{H}_{\mathrm{o}} \mathrm{T}_{\mathrm{om}}$ & $\begin{array}{l}\text { Rec }(\mathrm{m}) \\
\text { measured }\end{array}$ & Rec/ $\mathrm{D}_{\text {n50 }}$ & Remark \\
\hline 3 & 0.25 & 0.074 & 1.55 & 1.12 & 0.031 & 1.42 & 39.2 & 28.3 & 0.010 & 0.32 & \\
3 & 0.25 & 0.092 & 1.55 & 1.24 & 0.031 & 1.77 & 48.7 & 39.0 & 0.024 & 0.77 & \\
3 & 0.25 & 0.109 & 1.73 & 1.31 & 0.031 & 2.09 & 64.4 & 48.8 & 0.042 & 1.35 & Little breaking \\
3 & 0.25 & 0.121 & 1.89 & 1.32 & 0.031 & 2.32 & 78.1 & 54.6 & 0.070 & 2.26 & Breaking \\
3 & 0.25 & 0.130 & 2.04 & 1.37 & 0.031 & 2.50 & 90.6 & 60.8 & 0.097 & 3.13 & Breaking \\
4 & 0.25 & 0.074 & 1.55 & 1.12 & 0.031 & 1.42 & 39.2 & 28.3 & 0.022 & 0.71 & \\
4 & 0.25 & 0.092 & 1.55 & 1.24 & 0.031 & 1.77 & 48.7 & 39.0 & 0.054 & 1.74 & \\
4 & 0.25 & 0.109 & 1.73 & 1.31 & 0.031 & 2.09 & 64.4 & 48.8 & 0.085 & 2.74 & Litle breaking \\
4 & 0.25 & 0.123 & 1.89 & 1.37 & 0.031 & 2.36 & 79.4 & 57.6 & 0.114 & 3.68 & Breaking \\
4 & 0.25 & 0.131 & 2.13 & 1.46 & 0.031 & 2.52 & 95.3 & 65.3 & 0.122 & 3.94 & 3reaking \\
\hline
\end{tabular}

Incident wave heights were measured with 5 wave gauges about 3-4 $\mathrm{m}$ in front of the berm breakwater. With a depth of only $0.25 \mathrm{~m}$ at the toe of the structure, there was some breaking of the largest waves if the wave height exceeded roughly 0.10 or $0.11 \mathrm{~m}$. It means that for those test conditions the Rayleigh distribution was not achieved. This is indicated in Table 2. In first instance all results will be used, but later on this will be limited to the two lowest test conditions only.

\section{Myhra (2005)}

The tests for the Sirevåg breakwater were further elaborated by Myhra (2005). He tested the breakwater cross-section shown in Figure 1 and an alternative cross-section where only class I rock was used in the berm. He tested both orderly placement and dumping. From these tests only his test 2 meets the requirements of the Icelandic-type berm breakwater and orderly placed class I rock above water.

The structure was built on a 1:30 sloping foreshore with a water depth at the toe of the structure of $0.26 \mathrm{~m}$, in scale $1: 70$. This also means that the highest waves were breaking on the foreshore. In these tests the incident wave height was measured in front of the 1:30 foreshore and not 
in front of the structure. The two largest wave conditions gave breaking wave heights near the structure and will in second instance be ignored. Six profiles were measured along the structures. Table 3 gives all results. The recession as given in Table 3 is the mean of these six profiles.

Table 3. Results of test 2 of Myhra (2005)

\begin{tabular}{|c|c|c|c|c|c|c|c|c|}
\hline $\mathbf{H}_{\mathbf{s}}(\mathbf{m})$ & $\mathbf{T}_{\mathbf{p}}(\mathbf{s})$ & $\mathbf{T}_{\mathbf{n}}(\mathbf{s})$ & $\mathbf{D}_{\mathrm{n} 50}(\mathbf{m})$ & $\mathbf{H}_{\mathbf{o}}$ & $\mathbf{H}_{\mathbf{o}} \mathbf{T}_{\mathrm{op}}$ & $\mathbf{H}_{\mathbf{o}} \mathbf{T}_{\text {Jm }}$ & $\begin{array}{c}\text { Rec/ } \mathbf{D}_{\mathbf{n} 50} \\
\text { Average }\end{array}$ & Remark \\
\hline 3.3 & 10.8 & 9.24 & 2.07 & 0.95 & 22.3 & 19.1 & 0.02 & \\
4.3 & 11.96 & 10.1 & 2.07 & 1.24 & 32.2 & 27.2 & 0.29 & \\
5.3 & 13.14 & 11.1 & 2.07 & 1.52 & 43.6 & 36.8 & 0.70 & \\
6.3 & 14.22 & 11.56 & 2.07 & 1.81 & 56.1 & 45.6 & 1.44 & \\
7.3 & 15.39 & 12.42 & 2.07 & 2.10 & 70.3 & 56.8 & 2.03 & breaking waves \\
8.3 & 14.22 & 11.83 & 2.07 & 2.39 & 73.9 & 61.5 & 2.46 & breaking waves \\
\hline
\end{tabular}

\section{Sveinbjörnsson (2008)}

The primary goal of the tests performed by Sveinbjörnsson (2008) was to find design guidance about the depth on the down slope of the transition of class I to class II rock. Secondary goals were to find guidance about the part of the berm that should be covered by class I rock and about recession of the berm. The tests are very valuable, but it is a pity that earlier work in MAST II (1996 and 1997) was not considered, as well as the possibility of calculating dynamic reshaping by BREAKWAT.

The main conclusions from Sveinbjörnsson (2008) are:

1. Class I stones on the berm are recommended to reach at least further into the berm than expected recession from a design storm.

2. Class I stones are recommended to reach below LAT as far down as:

$\mathrm{h}_{\mathrm{l-II}} \geq 1.45 \cdot \Delta \mathrm{D}_{\mathrm{n} 50}$, Class I or

$h_{1-I I} \geq 1.85 \cdot \Delta D_{n 50}$, Class II,

where $h_{1-I}$ is the transition from class I to class II rock on the down slope. The one of the two that gives the larger $h_{1-\mid 1}$ in each case is the recommended choice.

3. If there are more of Class I stones available after meeting the recommendations 1 and 2, they should be placed on the berm.

4. Class II stones should in any case reach at least down to the transition of the original and the expected reshaped profile, $h_{f}$.

Conclusions 1 and 2 indicate that class I rock should be present far enough on the berm (determined by possible recession of this berm) and far enough down the slope. As the test set-up was determined in such a way to be able to indeed establish these transitions from class I to class II rock, there were tests where the class II rock influenced the results (recession) of the tests. In the further analysis these tests are not taken into account, as they do not fall within the boundary conditions set for the Icelandic-type berm breakwater. Also tests exceeding the maximum stability number (giving dynamically stable reshaping) were deleted. 
The tested cross-sections are given in Figure 6. Appendix A4 in Sveinbjörnsson (2008) gives the measured profiles and these were analysed to establish which tests where not influenced by the position of the class II rock. Table 4 gives all selected tests, including recession data, which were sent by Sveinbjörnsson on request.

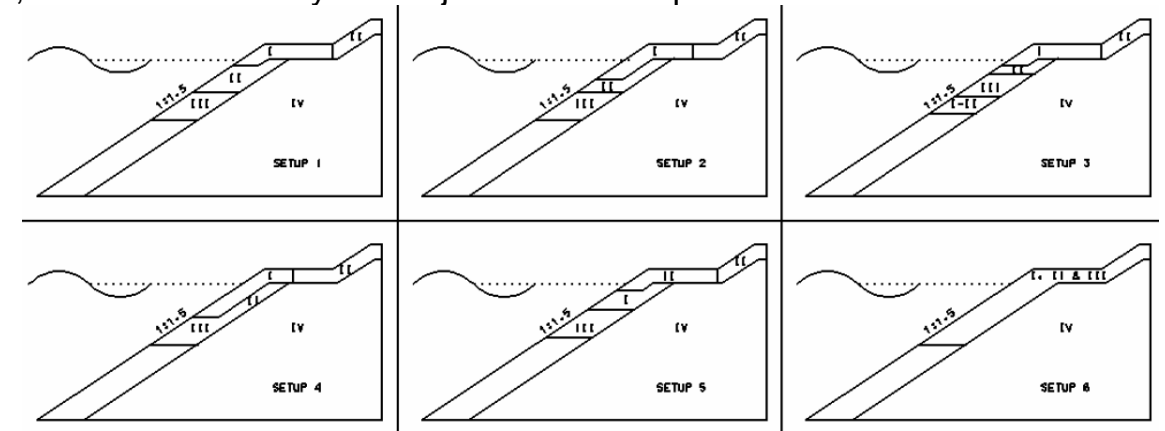

Figure 6. Cross-sections tested by Sveinbjörnsson (2008)

Table 4. Selected tests of Sveinbjörnsson (2008) with recession data

\begin{tabular}{|c|c|c|c|c|c|c|c|c|c|c|}
\hline $\begin{array}{l}\text { set-up } \\
\text { sets }\end{array}$ & $\begin{array}{c}\text { water depth } \\
\text { (m) }\end{array}$ & $\mathrm{H}_{\mathrm{s}}(\mathrm{m})$ & $T_{v}(s)$ & $T_{m}(s)$ & $D_{n 50}(m)$ & $\mathrm{H}_{3}$ & $\mathrm{H}_{\mathrm{o}} \mathrm{T}_{\text {od }}$ & $\mathrm{Ho}_{\mathrm{o}} \mathrm{T}_{\mathrm{om}}$ & $\operatorname{Rec}(\mathrm{cm})$ & $\operatorname{Rec} / D_{\text {n50 }}$ \\
\hline 1 & 0.590 & 0.088 & 1.12 & 1.04 & 0.032 & 1.55 & 30.5 & 28.3 & 0.000 & 0.00 \\
\hline 1 & 0.590 & 0.103 & 1.29 & 1.12 & 0.032 & 1.82 & 41.1 & 35.7 & 0.000 & 0.00 \\
\hline 1 & 0.645 & 0.084 & 1.15 & 1.05 & 0.032 & 1.48 & 29.9 & 27.3 & 0.000 & 0.00 \\
\hline 1 & 0.645 & 0.101 & 1.29 & 1.12 & 0.032 & 1.78 & 40.3 & 35.0 & 0.019 & 0.61 \\
\hline 2 & 0.590 & 0.109 & 1.17 & 1.12 & 0.032 & 1.92 & 39.4 & 37.7 & 0.031 & 0.98 \\
\hline 2 & 0.590 & 0.130 & 1.33 & 1.18 & 0.032 & 2.30 & 53.4 & 47.4 & 0.132 & 4.11 \\
\hline 2 & 0.590 & 0.085 & 1.23 & 1.07 & 0.032 & 1.50 & 32.3 & 28.1 & 0.000 & 0.00 \\
\hline 2 & 0.590 & 0.103 & 1.29 & 1.12 & 0.032 & 1.82 & 41.1 & 35.7 & 0.020 & 0.62 \\
\hline 2 & 0.590 & 0.122 & 1.37 & 1.21 & 0.032 & 2.15 & 51.7 & 45.6 & 0.029 & 0.90 \\
\hline 2 & 0.590 & 0.137 & 1.41 & 1.27 & 0.032 & 2.42 & 59.7 & 53.8 & 0.107 & 3.33 \\
\hline 2 & 0.645 & 0.084 & 1.18 & 1.05 & 0.032 & 1.48 & 30.6 & 27.3 & 0.000 & 0.00 \\
\hline 2 & 0.645 & 0.102 & 1.29 & 1.12 & 0.032 & 1.80 & 40.7 & 35.3 & 0.022 & 0.70 \\
\hline 2 & 0.645 & 0.120 & 1.37 & 1.21 & 0.032 & 2.12 & 50.8 & 44.9 & 0.048 & 1.49 \\
\hline 2 & 0.645 & 0.136 & 1.42 & 1.26 & 0.032 & 2.40 & 59.7 & 53.0 & 0.158 & 4.93 \\
\hline 2 & 0.645 & 0.158 & 1.53 & 1.35 & 0.032 & 2.79 & 74.7 & 65.9 & 0.221 & 6.91 \\
\hline 4 & 0.590 & 0.085 & 1.28 & 1.07 & 0.032 & 1.50 & 33.6 & 28.1 & 0.000 & 0.00 \\
\hline 4 & 0.590 & 0.103 & 1.29 & 1.12 & 0.032 & 1.82 & 41.1 & 35.7 & 0.000 & 0.00 \\
\hline 4 & 0.590 & 0.123 & 1.37 & 1.22 & 0.032 & 2.17 & 52.1 & 46.4 & 0.057 & 1.78 \\
\hline 4 & 0.590 & 0.137 & 1.41 & 1.26 & 0.032 & 2.42 & 59.7 & 53.4 & 0.120 & 3.74 \\
\hline 4 & 0.590 & 0.084 & 1.23 & 1.07 & 0.032 & 1.48 & 31.9 & 27.8 & 0.000 & 0.00 \\
\hline 4 & 0.590 & 0.102 & 1.29 & 1.13 & 0.032 & 1.80 & 40.7 & 35.6 & 0.000 & 0.00 \\
\hline 4 & 0.590 & 0.119 & 1.37 & 1.22 & 0.032 & 2.10 & 50.4 & 44.9 & 0.086 & 2.69 \\
\hline 4 & 0.590 & 0.135 & 1.39 & 1.27 & 0.032 & 2.38 & 58.0 & 53.0 & 0.133 & 4.16 \\
\hline 4 & 0.645 & 0.084 & 1.16 & 1.05 & 0.032 & 1.48 & 30.1 & 27.3 & 0.000 & 0.00 \\
\hline 4 & 0.645 & 0.102 & 1.29 & 1.12 & 0.032 & 1.80 & 40.7 & 35.3 & 0.032 & 1.00 \\
\hline 4 & 0.645 & 0.121 & 1.36 & 1.21 & 0.032 & 2.14 & 50.9 & 45.3 & 0.083 & 2.59 \\
\hline 5 & 0.590 & 0.086 & 1.26 & 1.07 & 0.025 & 1.94 & 48.5 & 41.2 & 0.000 & 0.00 \\
\hline 5 & 0.590 & 0.100 & 1.31 & 1.12 & 0.025 & 2.26 & 58.6 & 50.1 & 0.000 & 0.00 \\
\hline 5 & 0.065 & 0.083 & 1.13 & 1.05 & 0.025 & 1.88 & 42.0 & 39.0 & 0.000 & 0.00 \\
\hline 5 & 0.065 & 0.100 & 1.29 & 1.13 & 0.025 & 2.26 & 57.7 & 50.6 & 0.075 & 3.02 \\
\hline
\end{tabular}

The profiles were measured only in one line across the cross-section and with a rod with a flexible square plate of $2.5 \mathrm{~cm} \times 2.5 \mathrm{~cm}$. Earlier tests, as in MAST II (1996 and 1997) and Van der Meer (1988) were performed for various profiles (and averaged) and were performed with a semi-sphere as foot plate with a diameter half of the covering diameter of the rock. The different methods may give different results on recession. The main influence on reliability would be to take the average of a 
number of profiles or to take only one profile. As recession for Icelandictype berm breakwaters is close to static stability it is much more reliable to take the average of a number of profiles, assuming that recession is evenly distributed.

\section{ANALYSIS}

Figure 7 gives all results of Tables 2-4, together with equation 1 . This equation is also given in Figure 3 , but it should be noted that the confidence curves in Figure 7 are given by one standard deviation, where it are two standard deviations in Figure 3 . The first and encouraging conclusion is that all the data points are much closer together than in the final graph of PIANC (2003). This is also shown in Figure 8, where the data points of Figure 7 are indicated in the graph of PIANC (2003).

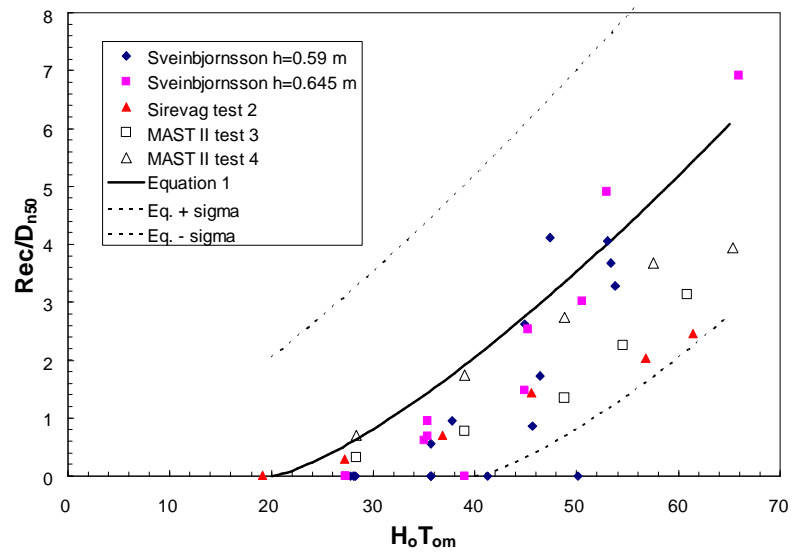

Figure 7. All selected data from Tables 2-4.

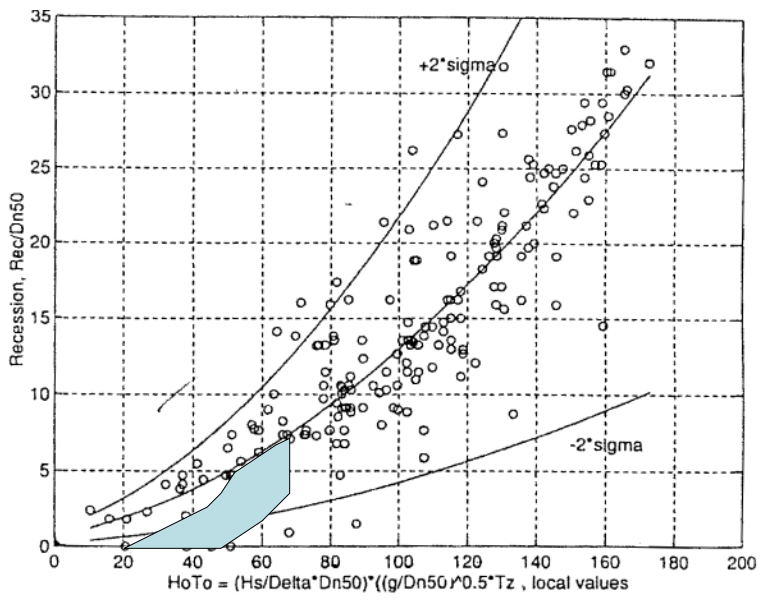

Figure 8. Data from Figure 7 in data from PIANC (2003). 
A closer look at Figure 7 shows that the data of MAST II and Myhra (Sirevåg test 2) for the larger values of $\mathrm{H}_{0} \mathrm{~T}_{\mathrm{om}}$-values are lower than those from Sveinbjörnsson, where they are mixed for the lower values. The reason for this could be that the larger values lead to (some) wave breaking on the foreshore, where the highest waves break most and where the Rayleigh distribution of waves does not longer apply. It is for this reason that in Figure 9 the data with wave breaking (as indicated in Tables 2 and 3) have been deleted.

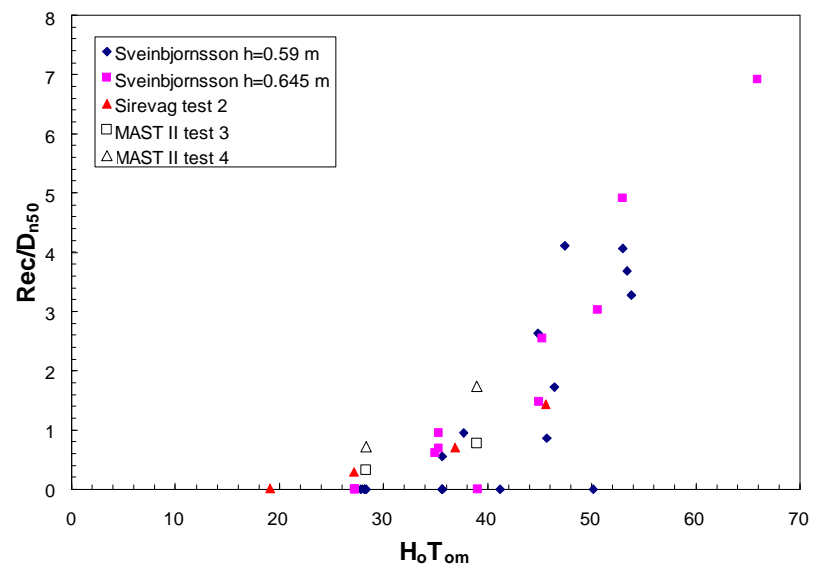

Figure 9. All reliable recession data for an Icelandic-type berm breakwater

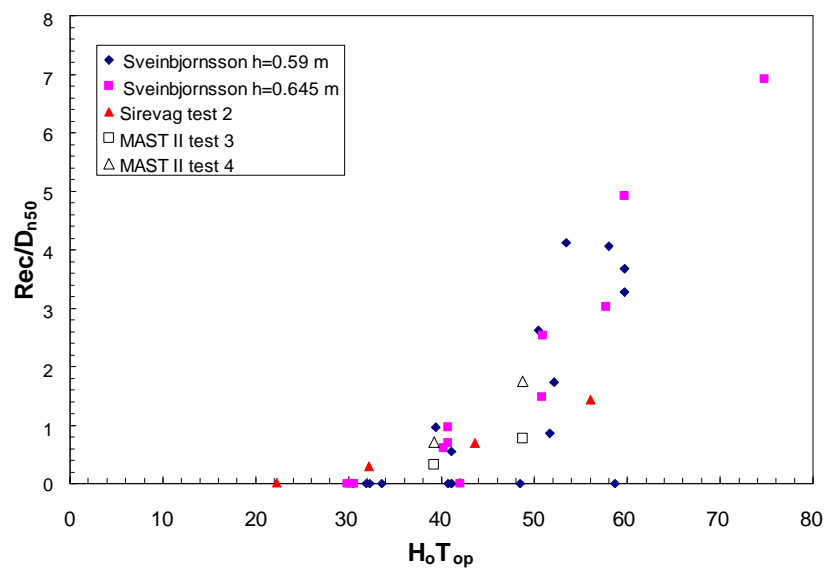

Figure 10. All reliable recession data for an Icelandic-type berm breakwater, using the peak period $T_{p}$

All data mix well together and show a clear trend. Before any formula will be developed, two other aspects will be discussed. The first one is the use of the mean period $T_{m}$ versus the peak period $T_{p}$. 
Nowadays one would prefer the spectral period $T_{m-1,0}$, as this period is closer to the peak period than the mean period and it can be determined independent of the shape of the spectrum (bi-modal or very flat spectra). These periods were not available, however, for the 9 tests considered here. In Van der Meer (1988) it appeared that for static stability the mean period gave slightly better results than the peak period, considering different spectral widths. It is for this reason that the mean period was only considered in the profile analysis of Van der Meer (1988) and it is for this reason that also PIANC (2003) considered only $\mathrm{H}_{\mathrm{o}} \mathrm{T}_{\mathrm{om}}$, using the mean period. Nevertheless, it could be possible that the peak period gives results with less scatter. Therefore, Figure 9 was re-plotted, but now with the peak period, giving $\mathrm{H}_{\mathrm{o}} \mathrm{T}_{\mathrm{op}}$. Figure 10 gives the results.

There is not much difference between Figures 9 and 10. A small difference is that the data of MAST II for the lowest wave conditions shift a little more to the right in Figure 10, giving a clearer picture about the start of recession. It might be for this reason that there would be a slight preference to use $T_{p}$ instead of $T_{m}$.

Another aspect is the influence of the wave period itself. Sveinbjörnsson (2008) concludes that probably the wave period has not too much effect and that the stability number $\mathrm{H}_{0}=\mathrm{H}_{s} / \Delta \mathrm{D}_{\mathrm{n} 50}$ could be a better parameter. But he used only fixed wave steepness and this of course hides to some extent the influence of the wave period on recession. Figure 11 gives the recession data as a function of the stability number only.

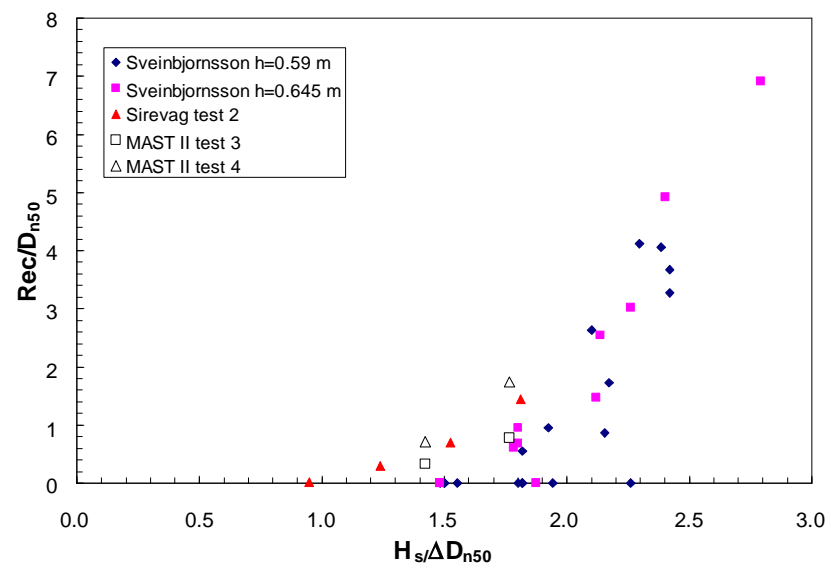

Figure 11. All reliable recession data for an Icelandic-type berm breakwater, using the stability number $H_{0}=H_{s} / \Delta D_{n 50}$

The scatter becomes larger in Figure 11, certainly in the area for small recession. The Sirevåg data shift to the left, due to the fact that these tests were performed with a longer wave period (or lower wave steepness). It may be concluded, as before, that the wave period 
certainly has influence on stability as well as on reshaping and that it is better to use $\mathrm{H}_{0} T_{\mathrm{op}}$, or as even better alternative $\mathrm{H}_{0} T_{\text {om- } 1,0}$, with the spectral parameter $\mathrm{T}_{\mathrm{m}-1,0}$.

The following formula fits the data points in Figure 12 fairly well:

with:

$$
\mathrm{Rec} / \mathrm{D}_{\mathrm{n} 50}=0.032\left(\mathrm{H}_{\mathrm{o}} \mathrm{T}_{\mathrm{op}}-\mathrm{Sc}\right)^{1.5}
$$

and:

$$
\begin{aligned}
& \mathrm{Rec} / D_{\text {n50 }}=0 \text { for } \mathrm{H}_{\mathrm{o}} \mathrm{T}_{\text {op }}<\mathrm{Sc} \\
& \mu(\mathrm{Sc})=35 \text { and } \sigma(\mathrm{Sc})=5 \text { and } \mathrm{H}_{\mathrm{o}} \mathrm{T}_{\text {op }}<70
\end{aligned}
$$

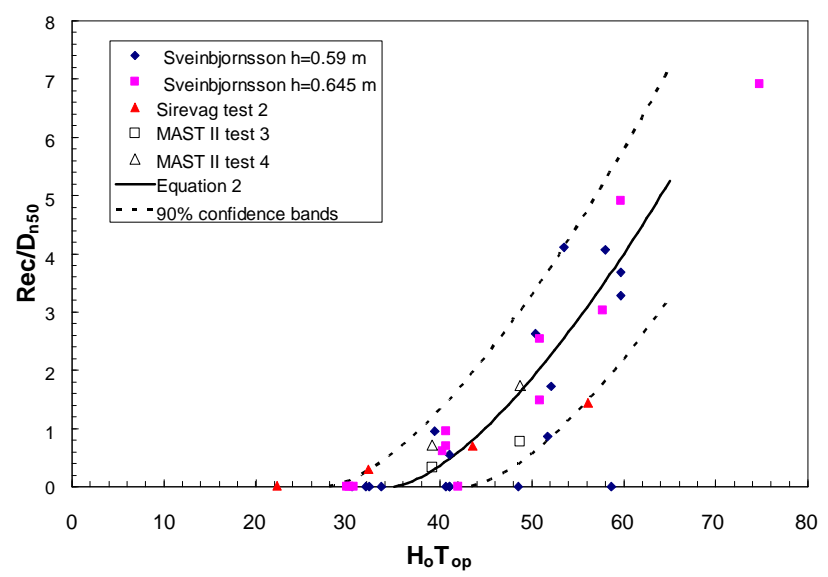

Figure 12. All reliable recession data for an Icelandic-type berm breakwater, using the peak period $T_{p}$ and showing the design formula 2 with $90 \%$ confidence band.

Equation 2 shows that the start of recession is estimated at $\mathrm{H}_{0} \mathrm{~T}_{\mathrm{op}}=$ 35 (the mean of Sc). The standard deviation of $\mathrm{Sc}=5$, which is 4 times smaller than in equation 1! Equation 2 can be used as design equation for Icelandic-type berm breakwaters, up to $\mathrm{H}_{0} \mathrm{~T}_{\mathrm{op}}=70$. Beyond that condition the structure is close to dynamic stability, which is not acceptable for Icelandic-type berm breakwaters.

Equation 2 and Figures 10 and 12 can also be described as:

- No damage is expected for $\mathrm{H}_{\mathrm{o}} \mathrm{T}_{\mathrm{op}}=35$

- Zero to one diameter recession at the edge of the berm is expected at $\mathrm{H}_{\mathrm{o}} \mathrm{T}_{\mathrm{op}}=40$

- One to three diameters recession at the edge of the berm is expected at $\mathrm{H}_{\mathrm{o}} \mathrm{T}_{\mathrm{op}}=50$

Compared to the design condition of $\mathrm{H}_{0}=\mathrm{H}_{\mathrm{s}} / \Delta \mathrm{D}_{n 50}=2$ one can conclude that this is about similar to $\mathrm{H}_{0} \mathrm{~T}_{\mathrm{op}}=45$, which means that roughly one diameter recession is accepted during design conditions. But equation 2 includes the influence of the wave period, where the stability number does not. 


\section{CONCLUSIONS}

For dynamic stable breakwaters and single beaches the reshaped profile is of importance. For reshaped statically stable berm breakwaters, like the Icelandic-type berm breakwater, the reshaping or recession is limited. The present paper focuses on the stability and recession of the Icelandic-type berm breakwater. The PIANC (2003) recession data does not represent well the Icelandic-type berm breakwater. Requirements for the type of data needed to get more reliable results for the Icelandic-type are defined and three data sets from wave flume tests are identified. All those datasets are based on experiments on Icelandic-type berm breakwaters where the recession of the berm occurs in the narrow graded class I rocks and is not influenced by the smaller rock classes. The construction of the rock of class I should be done with care.

Moreover the analysis is focused on the part of the recession process that is relevant for Icelandic-type berm breakwaters, that is relatively early in the damage process, $\mathrm{H}_{0} \mathrm{~T}_{\text {op }}<70$. From the analysis of those data sets, a new formula for the recession of the Icelandic-type berm breakwater is presented, Equation 2, where the mean recession along the tested berm breakwaters is a function of $\mathrm{H}_{\mathrm{o}} \mathrm{T}_{\mathrm{op}}$

\section{REFERENCES}

MAST II, 1997. Berm breakwater structures. Final Report MAST-Contract MAS2-CT94-0087.

MAST II, 1996. Influence of Permeability and Stone Gradation. MAST II Berm breakwater structures. Contract MAS2-CT94-0087.

Myhra, H., 2005. Berm breakwaters. Influence of construction method and storm duration on stability. Ice ride-up. MSc-thesis NTNU.

PIANC, 2003. State-of-the-Art of Designing and Constructing Berm Breakwaters. WG40.

Sigurdarson, S., Smarason, O.B., Viggosson, G. and Bjørdal, S., 2006. Wave height limits for the statically stable Icelandic-type Berm Breakwater, Proc. of $30^{\text {th }}$ Int. Conf. on Coastal Engineering, ASCE.

Sigurdarson, S., J.W. van der Meer, H.F. Burcharth and J. Dalsgaard Sørensen, 2007. Optimum safety levels and design rules for the Icelandic type berm breakwater. Proc. Coastal Structures, Venice, Italy.

Sveinbjörnsson, P.I., 2008. Stability of Icelandic type Berm Breakwaters. MScthesis TU Delft.

Van der Meer, J.W., 1988. Rock slopes and gravel beaches under wave attack. PhD-thesis TU Delft. 
KEYWORDS - ICCE 2008

BERM RECESSION OF THE ICELANDIC-TYPE BERM BREAKWATER

Sigurdur Sigurdarson, Jentsje W van der Meer, Alf Tørum and Roberto Tomasicchio

Abstract number 1450

Breakwaters

Berm Breakwaters

Coastal structures

Stable berm breakwater

Reshaping

Stability 